\title{
FUNGSI OLAH TEMPAT KEJADIAN PERKARA (TKP) GUNA MENGUNGKAPKAN KASUS PENGANIAYAAN BERAT DITINJAU DARI SUDUT HUKUM ACARA PIDANA
}

\author{
Oleh: \\ Lestari Victoria Sinaga ${ }^{1)}$ \\ Mhd. Yuda Mulyawan Simatupang ${ }^{2)}$ \\ Universitas Darma Agung, Medan 1,2) \\ E-mail: \\ Missthary35@gmail.com $^{1)}$ \\ Mhd.simatupang@gmail.com $^{2)}$
}

\begin{abstract}
This study aims at revealing cases of severe maltreatment through crime scene crime scenes. One of the investigation processes can convince the investigator in determining the suspect in handling the crime scene (TKP) where it is divided into 2 namely the First Actions at the crime scene (TPTKP) and processing of the crime scene (olah TKP) from the legislation. As for the results obtained are the methods used by public observations, sketches and photographs, handling victims, handling witnesses and suspects and handling evidence through CCTV footage. In cases of severe maltreatment from the crime scene results can be used through other tools-others such as watering the face with Lombok water, acidic substances, sulfur, saltpeter, vinegar, so that the skin on the face burns, or inserting poisons in food. Not only can it be proven analytically or through autopsy, but it depends on the performance of criminal investigators at the crime scene and eyewitness examination.
\end{abstract}

\section{Keywords: Crime Scene, Severe Persecution, Criminal Procedure Code}

\begin{abstract}
Tujuan penelitian ini adalah untuk mengungkap kasus penganiayaan berat melalui olah TKP dari Tempat kejadian perkara. Salah satu proses penyidikan dapat meyakinkan penyidik dalam penetapan tersangka dalah penanganan tempat kejadian perkara (TKP) dimana dibagi 2 yaitu Tindakan Pertama di tempat kejadian perkara (TPTKP) dan pengolahan tempat kejadian perkara (Olah TKP).Metode yang digunakan adalah yuridis nomratif, yakni mengkaji dari peraturan perundang-undangan.Adapun hasil yang didapat adalah Cara yang digunakan pengamatan umum, sketsa dan foto, penanganan korban,penanganan saksi dan tersangka dan penangan barang bukti melalui rekaman CCTV.Dalam kasus Penganiayaan berat dari hasil olah TKP bisa digunakan melalui alat lain-lain seperti menyiram muka dengan air Lombok, zat asam, belirang, asam sendawa, asam cuka, sehingga kulit muka terbakar, atau memasukan racun dalam makanan.Tidak hanya dapat dibuktikan secara analitik atau melalui autopsi saja tetapi tergantung dari kinerja penyidik krimininal pada Olah TKP dan pemeriksaan saksi mata.
\end{abstract}

Keywords: Tempat kejadian perkara, penganiayaan berat, KUHAP 


\section{PENDAhuluan}

Pada Tahun 2017 di Indonesia heboh dengan pemberitaan penyiraman air keras terhadap Novel, seorang penyidik senior Komisi Pemberantasan Korupsi yang mengakibatkan kerusakan mata Novel Baswedan secara permanen. Penyerangan terhadap Novel sendiri, sudah terjadi dua tahun lalu.Persisnya pada 11 April 2017 di sekitaran kediamannya di Kelapa Gading, Jakarta Utara.

kasus ini juga janggal, karena tuntutan hukuman kurungan 1 tahun penjara bagi terdakwa penyerang senior KPK Novel Baswedan ini dan proses persidangan aneh terkesan penuntut umum menjadi penasehat hukum. Sebagaimana penganiayaan berat kasus ini juga tidak sebagaimana mestinya.

Kebencian Rahmat Kadir Mahulatte, yang didakwa melakukan penganiayaan berat terencana terhadap Novel Baswedan yang tidak menghargai jiwa korsa tidak mengorbankan anak buah, serta institusi yang membesarkannya menjadi pemicu bagi terdakwa memberikan pelajaran terhadap saksi korban.

Fokus membongkar kasus penyerangan Novel ini sampai diinstruksikan oleh Presiden Joko Widodo agar segera terungkap cepat pelaku terornya. Menurut Presiden, penyerangan air keras terhadap Novel Bswedan ini bukan hanya kejahatan biasa, tetapi kejahatan diduga dan sudah direncakan dan tersktur. Presiden Joko Widodo bahkan membentuk Tim Teknis yang didalamnya tergabung 120 polisi, Densus 88. Tapi jika belum selesai juga, masa kerja tim akan diperpanjang tiga bulan lagi.

Polisi dalam menemukan analisis tempat kejadian perkara, memeriksa saksi, analiss rekaman CCTV, dan analisis skestsa wajah terduga pelaku. Olah TKP adalah kunci utama dari penyidikan peristiwa pidana, karena TKP adalah titik tolak pekerjaan awal tim, karena sesuai dengan teori pembuktian setiap peristiwa pidana selalu bermula dari TKP. olah TKP mempunyai bobot 60 sampai 70 persen dalam pengungkapan peristiwa pidana.

Serangan berupa penyiraman air keras oleh tiga orang tak dikenal saat pagi hari waktu itu, mengakibatkan mata kiri Novel rusak permanen. Meski sudah terjadi dua tahun lalu, olah TKP yang akan dilakukan oleh Tim Teknis nantinya akan melibatkan seluruh sumber daya kepolisian.

Olah TKP juga menyertakan pemeriksaan ulang seluruh barang bukti, dan petunjuk dari lokasi peristiwa.Termasuk rekaman kamera pemantau lingkungan di sekitar lokasi, dan juga di sejumlah titik yang terkait dengan lintasan insiden penyiraman.olah TKP ini, melibatkan labfor (laboratorium forensik), inafis, dan tim informatika dan teknologi.

Dalam kasus Penganiayaan berat ini dengan Memakai alat lain-lain seperti menyiram muka dengan air Lombok, zat asam, belirang, asam sendawa, asam cuka, sehingga kulit muka terbakar, atau memasukan racun dalam makanan.Tidak hanya dapat dibuktikan secara analitik atau melalui autopsi saja tetapi tergantung dari kinerja penyidik krimininal pada Olah TKP dan pemeriksaan saksi mata. Penjelasan ini harus dikategorikan untuk menyingkirkan kemungkinan bahwa luka penganiayaan disebabkan oleh sesuatu hal, penyalahgunaan substansi berbahaya yang disengaja, atau merupakan tindakan perencanaan membunuh.

Hasilpengungkapan oleh TPF sebagai lini lain dalam penyidikanakan berlanjut dengan pemeriksaan sejumlah saksi-saksi yang pernah memberikan pengakuan ke 
penyidik, dan saksi-saksi baru yang mempunyai informasi dan petunjuk.

\section{TINJAUAN PUSTAKA \\ a Pengertian Tempat Kejadian Perkara}

Tempat Kejadian Perkara (TKP) adalah suatu tempat penemuan barang bukti atau tempat terjadinya tindak pidana atau kecurigaan suatu tindak pidana, merupakan suatu persaksian.

Pengertian Tempat Kejadian Perkara (TKP) di dalam petunjuk lapangan No. Pol: Skep/1205/IX/2000 tentang Penanganan Tempat Kejadian Perkara (TKP) terbagi menjadi 2 (dua) yakni:

a. Tempat dimana suatu tindak pidana dilakukan/terjadi atau akibat yang ditimbulkannya.

b. Tempat-tempat lain yang berhubungan dengan tindak pidana tersebut dimana barang barang bukti, tersangka atau korban dapat ditemukan.

Tempat Kejadian Perkara Pasal 1 ayat (19) PERKAP POLRI Nomor 6 Tahun 2010 tentang Manajemen Penyidikan Oleh Penyidik Pegawai Negeri sipil yaitu : " Tempat Kejadian Perkara adalah yang selanjutnya disingkat TKP adalah tempat dimana suatu tindak pidana dilakukan/terjadi dan tempat-tempat lain, dimana tersangka dan/atau korban dan/atau barang bukti yang berhubungan dengan tindak pidana tersebut dapat ditemukan.

Hal tersebut sebagaimana tercantum juga pada asal 1 ayat (19) PERKAP POLRI Nomor 14 Tahun 2012 tentang Manajemen Penyidikan Tindak Pidana. Menurut Van Hamel yang dianggap sebagai TKP adalah : tempat di mana seorang pelaku itu telah melakukan sendiri perbuatannya, tempat di mana alat yang telah dipergunakan oleh seorang pelaku itu bekerja, tempat di mana akibat langsung diambil.
Fungsi Penyidikan adalah merupakan Fungsi teknik reserse Kepolisian yang mempunyai tujuan membuat suatu perkara menjadi jelas, yaitu dengan mencari dan menemukan kebenaran materiil yang selengkap-lengkapnya tentang suatu perubahan/tindak pidana yang telah terjadi. Pengertian dari penanganan Tempat Kejadian Perkara (TKP) adalah tindakan penyelidik atau penyidik atau penyidik pembantu berupa tindakan kepolisian yang dilakukan di TKP terdiri dari:

1. Tindakan Pertama di Tempat Kejadian Perkara (TPTKP), yaitu tindakan penyidik/penyidik pembantu TKP untuk:

a. Mengamankan Tempat Kejadian Perkara (TKP) serta dapat melarang setiap orang meninggalkan tempat selama pemeriksaan di tempat kejadian perkara selesai;

b. Mempertahankan Status Quo dan berusaha untuk tetap mempertahankan situasi/keadaan tempat kejadian perkara sebagaimana pada saat pertama TKP ditemukan dan ditangani;

c. Melakukan

pertolongan/perlindungan terhadap korban atau anggota masyarakat yang memerlukan pertolongan.

2. Olah Tempat Kejadian Perkara (OTKP) adalah tindakan penyidik/penyidik pembantu untuk memasuki Tempat Kejadian Perkara (TKP) dalam rangka melakukan pemeriksaan di TKP mencari informasi tentang terjadinya tindak pidana mengumpulkan / mengambil / membawa barang-barang bukti yang diduga ada hubungannya dengan tindak pidana yang terjadi untuk diambil alih penguasaannya atau menyimpan barang bukti tersebut guna kepentingan pembuktian.

Olah Tempat Kejadian Perkara (OTKP) merupakan rangkaian penyelidikan dimana penyidik bersama dengan unsur 
dukungan dari laboratorium kriminil dan kedokteran forensik berupaya mengungkapkan peristiwa yang telah terjadi dari bukti-bukti yang didapatkan di TKP.

\section{b Pengertian Penganiayaan Berat}

Pasal 354 KUHP merumuskan penganyiaan berat sebagai berikut:

1) Barangsiapa dengan sengaja melukai berat orang lain, dipidana karena melakukan penganiayaan berat dengan pidana penjara paling lama 8 tahun.

2) Jika perbuatan itu mengakibatkan kematian, yang bersalah dipidana dengan pidana penjara paling lama 10 tahun.

Mengingat pengertian penganiayaan seperti yang sudah diterangkan diatas dengan menghubungkannya pada rumusan penganiayaan berat diatas, maka pada penganiayaan berat mempunyai unsur-unsur sebagai berikut: Kesalahannya: kesengajaan; Perbuatan: melukai berat; Objeknya: tubuh orang orang lain; Akibat: luka berat Perbuatan melukai berat atau dapat disebut juga luka berat pada tubuh orang lain, haruslah dilakukan dengan sengaja. Kesengajaan disini haruslah diartikan secara luas, artinya termasuk dalam ketiga bentuk kesengajaan. Apabila dalam rumusan tindak pidana dirumuskan unsur kesengajaan, maka kesengajaan itu harus diartikan ketiga bentuk kesengajaan.

Dalam kasus Novel Baswedan ini, merupakan penganiayaan berencana dengan menyiramkan air keras ke muka sehingga Pasal 353 ayat 3 (penganiayaan berat) sama dengan Pasal 354 (penganiayaan berencana) sehingga memperberat pidana dalam penganiayaan berat.

Secara kita tahu, tindak pidana penganiayaan dibedakan menjadi:

a Penganiayaan biasa Pasal 351 KUHP b Peganiayaan luka berat berencana diatur Pasal 353 KUHP yang mengakibatkan luka berat

c Penganiayaan berat dengan berencana diatur Pasal 355 KUHP.

Ancaman pidana dari Pasal 355 ayat 1 KUHP sendiri adalah pidana penjara paling lama dua belas tahun. Pasal 355 ayat 1, berbunyi: Penganiayaan berat yang dilakukan dengan rencana terlebih dahulu, diancam dengan pidana penjara paling lama dua belas tahun. Sedangkan pidana bagi Pasal 353 ayat 2 adalah pidana penjara tujuh tahun.Tetapi pada kasus ini hanya dituntut Jaksa 1 tahun.

\section{METODE PENELITIAN}

Metode pendekatan yang dilakukan dalam penelitian ini adalah metode yuridis normatif, yaitu Penelitian Hukum yang dilakukan dengan cara meneliti bahan pustaka atau data sekunder.

a. Data primer, yakni data yang diperoleh dengan cara penelitian perpustakaan.

b. Data sekunder, yang terdiri dari :

1) Bahan hukum primer adalah Kitab Undang-UndangHukum

Pidana (KUHP), UU No. 2 Tahun 2002 tentang Kepolisian dan UU No. 8 Tahun 1981 tentang Kitab Undang-Undang Hukum Acara Pidana (KUHAP).

2) Bahan hukum sekunder atau bahanbahan hukum yang memberikan penjelasan mengenai bahan hukum primer, yaitu bahan-bahan perpustakaan yakni buku-buku, artikel internet dan literature lain berkaitan dengan Tempat Kejadian Perkara.

3) Bahan hukum tertier, berupa bahanbahan hukum yang memberikan petunjuk maupun penjelasan terhadap bahan hukum primer dan 
sekunder, seperti Kamus, Ensiklopedia dan lain-lain.

\section{HASIL DAN PEMBAHASAN Penanganan Tempat Kejadian Perkara Sebagai Bagian Dari Tahap Penyidikan.}

Dalam melakukan penanganan tempat kejadian perkara guna mencari dan mengumpulkan bukti-bukti yang ada ditempat kejadian perkara penyidik juga harus berdasarkan peraturan perundangundangan yang berlaku seperti yang diatur dalam pasal 7 dan 111 Undang-Undang No.8 Tahun 1981 tentang KUHAP.Pengolahan TKP ini terdiri dari pengamatan umum (General observation), membuat sketsa dan pemotretan penanganan korban, saksi dan tersangka serta pengumulan barang bukti.

Ruang lingkup materi penanganan TKP ini adalah pemahaman peran penting TKP sebagai sumber awal keterangan terjadinya tindak pidana, tindakan- tindakan yang harus dilakukan oleh Polisi pada saat menerima laporan/menemukan langsung tindak pidana yang menjadi kewenangannya (Tindakan Pertama di TKP) dan tindakan-tindakan PPNS dalam melakukan penanganan TKP (Pengolahan TKP)

1. Pengamatan Umum.

Pengamatan umum ini penting karena dalam tahap ini penyidik yang perlu dicatat misalnya waktu tiba, alamat, keadaan cuaca, tempat kematian, kondisi tubuh korban dan lain-lain.Dari pengamatan ini kadang-kadang sudah dapat diperoleh kesan tentang motif modus operandi dan kapan terjadinya tindak pidana yang sedang diselidiki nya.

2. Sketsa dan Foto.

Sketsa merupakan gambar sederhana yang menunjukan letak dan posisi tubuh diantara obyek yang tidak bergerak terhadap obyek-obyek lain yang ada di TKP. Dengan sketsa penyidik dapat menggambarkan secara singkat apa yang perlu dan menyingkirkan hal-hal yang tak perlu tampak di foto.

Fungsi lain dari foto adalah sebagai penyegar daya ingat siapa saja yang berkepentingan terhadap tindak pidana yang telah terjadi. Agar supaya foto ini dapat dipergunakan di pengadilan diperlukan teknis pemotretan oleh petugas khusus yang terlatih.

3. Penanganan Korban.

Dalam menangani seorang korban perlu dibedakan apakah korban hidup, diragukan hidup atau mati.Pada setiap korban hidup atau diragukan kehidupannya, prinsip tindakan pertolongan pertama harus diprioritaskan.Sementara tindakan pertolongan pertama diberikan penyidik meminta bantuan petugas kesehatan atau segera melarikannya ke Rumah Sakit terdekat.

4. Penanganan Saksi dan Tersangka.

Baik dari tersangka maupun saksi diadakan wawancara ataupun pemeriksaan singkat untuk mengetahui keterlibatan dalam tindak pidana yang telah terjadi.Berdasarkan keterngan-keterangan tersebut dapat dicarai petunjuk selanjutnya guna pengembangan penyidikan yang sedang berjalan.

\section{Penanganan Barang}

Bukti.Penanganan barang bukti yang didapatkan dari TKP sebagai alat bukti telah terjadinya suatu tindak pidana

Untuk memudahkan petugas dalam menemukan barang bukti, maka dalam pelaksanaan pencarian mempergunakan cara tertentu, sebagaimana tercantum dalam Petunjuk Teknis No.Pol. JUKNIS/01/II/1982, sebagai berikut :

1. Metode Zone (Zone Methode), disebut juga sistem pembagian bidang, yaitu tempat dimana harus dicari sebelumnya dibagi atas bidang-bidang yang tertentu, sehingga tempat pencarian menjadi kecil. Untuk tiap-tiap bidang 
ditunjukan seorang pembantu tertentu yang ditugaskan untuk mencari seorang pembantu tertentu yang ditugaskan untuk mencari dibidang itu.

a. Caranya : Luas Tempat Kejadian Perkara (TKP) dibagi menjadi tempat bagian, dari tiap bagian dibagi-bagi menjadi empat bagian. Jadi masing-masing bagian $1 / 16$ bagian dari luas Tempat Kejadian Perkara (TKP) seluruhnya. Untuk tiap/tiap 1/16 bagian tersebut ditunjukan sampai empat petugas untuk menggeledanya.

b. Metode ini baik untuk pekarangan, rumah atau tempat tertutup.

2. Metode Spiral (Spiral Methode), yaitu pencarian dimulai dari tengahtengah tempat, kemudian berputar seerti jalannya jarum jam, makin membesar lingkaran (spiral), akhirnya semua tempat mendapat giliran dicari.

a. Caranya : 3 orang petugas atau lebih menjelajahi tempat kejadian dengan cara masing-masing berderet kebelakang (yang satu dibelakang yang lain) dengan jarak tertentu, kemudian bergerak mengikuti bentuk spiral berputar kearah dalam.

b. Metode ini baik di daerah yang lapang, bersemak atau berhutang.

3. Methode Strip dan Metode Strip Ganda (Strip Methode and Doble Strip Methode).

a. Caranya : 3 orang petugas masing-masing berdampingan yang satu dengan yang lain dalam jarak sama dan tertentu (sejajar) kemudian bergerak serentak dari lain dalam jarak yang sama dan tertentu (sejajar) kemudian bergerak serentak dari sisi lain di
Tempat Kejadian Perkara (TKP). Apabila dalam gerakan tersebut sampai di ujung sisi lebar yang lain gerakan masing berputar kearah semula.

b. Metode ini baik untuk daerah berlereng.

4. Metode Roda (Wheel Methode), yaitu pencarian dimulai dari ruang tengah lalu berjalan ke tepi seperti arahnya jari-jari roda, dengan demikian semua tempat dipelajari.

a. Caranya : beberapa orang petugas bergerak bersama sama kea rah luar dimulai dari titik tengah Tempat Kejadian , dimana masing-masing petugas menuju kea rah sasarannya sendiri-sendiri sehingga merupakan arah delapan penjuru angin.

Dalam pengungkapan kasus Novel ini segitiga, analisa TKP, titik tolak pekerjaan awal penyidik berawal dari teori pembuktian bahwa setiap peristiwa pidana bermula dari TKP. TKP menjadi 3 segitiga yang dimaksud penyidik, olah perkara, barang bukti dan tersangka yang dikemukakan tim penyidik. Untuk mengungkap identitas terduga pelaku penyerangan, Kepolisian Republik Indonesia telah meminta bantuan Kepolisian Australia, AFP, dimana ditemukan rekaman CCTV.

Karena dari hasil TKP dapat memperoleh keyakinan mendapatkan penetapan tersangka. Salah satu proses penyidikan dapat meyakinkan penyidik dalam penetapan tersangka dalah penanganan tempat kejadian perkara (TKP) dimana dibagi 2 yaitu Tindakan Pertama di tempat kejadian perkara (TPTKP) dan pengolahan tempat kejadian perkara (Olah TKP).

Novel Baswedan diserang oleh dua orang pengendara motor pada 11 April 2017 
seusai shalat subuh di Masjid Al-Ihsan dekat rumahnya. Pelaku menyiramkan air keras ke kedua mata Novel sehingga mengakibatkan kedua matanya rusak.

Olah TKP Tim Koordinator Orang Hilang dan Korban Tindak Kekerasan, menunjukan bahwa kepolisian dalam mengungkap kemampuan teknisnya secara maksimal. Karena berdasarkan Peraturan Kepala Kepolisian Negara Republik Indonesia Nomor 14 Tahun 2012 Tentang Manajemen Penyidikan Tindak PidanaPasal 12 ayat (1) Perkapolri 14/2012, kegiatan penyelidikan meliputi:

a pengolahan TKP;
b pengamatan (observasi);
c wawancara (interview);
d pembuntutan (surveillance);
e penyamaran (under cover);
f pelacakan (tracking); dan
g penelitian dan analisis dokumen

Dari sini bisa kita ketahui bahwa salah satu kegiatan penyelidikan adalah pengolahan TKP. Jadi, menjawab pertanyaan Anda, pengolahan TKP itu memiliki keterkaitan dengan proses penyelidikan karena pengolahan TKP merupakan bagian dari proses penyelidikan.

Dalam sebuah petunjuk lapangan (Juklap) Badan reserse Kriminal Polri Direktorat Tindak Pidana Umum yakni penanganan tindak pidana penganiayaan bahwa pengolahan TKP dilakukan penyidik Polris, dengan disaksikan orang yang melakukan penyerangan air raksa Novel Baswedan.

Tindakan pengamanan di TKP dilakukan dengan menutup dan mengamankan TKP (mempertahankan status quo) dengan membuat batas/tanda garis polisi (police line) di TKP bila lokasi memungkinkan.Atau membuat tanda patok batas TKP yang didasari hasil pengambilan titik-titik koordinat.
Selain itu, dalam Juklap tersebut juga disebutkan mengenai tahapan tindakan penanganan di TKP, antara lain: melakukan pemotretan dengan maksud untuk mengabadikan situasi TKP termasuk keberadaan saksi-saksi, kegiatan/aktivitas pertambangan dan barang bukti yang berada di TKP dan untuk memberikan gambaran nyata tentang situasi dan kondisi TKP serta untuk membantu melengkapi kekurangankekurangan dalam pengolahan TKP termasuk kekurangan-kekurangan dalam pencatatan dan pembuatan sketsa, obyek pemotretan TKP secara keseluruhan dan berbagai sudut, detail atau close-up terhadap setiap obyek yang diperlukan untuk penyidikan; dan pembuatan sketsa TKP. Sketsa dibuat dengan maksud untuk menggambarkan TKP seteliti mungkin dan sebagai bahan untuk menggambarkan kondisi TKP pada saat dilakukan olah TKP.

\section{SIMPULAN DAN SARAN}

\section{A. Simpulan}

1. Penanganan di Tempat Kejadian Perkara (TKP) oleh penyidik guna mengungkapakan kasus penganiayaan berat adalah melalui Tindakan Pertama di Tempat Kejadian Perkara (TPTKP) yaitu : membatasi dan menjaga Status Quo dari TKP, menyampaikan pemberitahuan dan tindakantindakan lain. dan melalui Pengolahan Tempat Kejadia Perkara (TKP) yaitu : pengamatan umum, sketsa dan foto, penanganan korban,penanganan saksi dan tersangka dan penangan barang bukti.

\section{B. Saran.}

1. Diharapkan kedepan Fungsi Olah Tempat Kejadian Perkara (OTKP) dapat lebih ditingkatkan dalam penyidikan guna membuat jelas dan terangnya suatu perkara pidana dan sangat penting dalam membantu 
proses pengungkapan kasus pembunuhan dan penyidikan yang dikirim untuk melakukan penyidikan adalah seorang perwira Polisi yang professional dan ditingkatkannya pendidikan tentang penyidikan di bidang polisi.

\section{DAFTAR PUSTAKA}

https://nasional.republika.co.id/berita/pvi29f 377/dua-tahun-usai-penyiraman-polisiperiksa-ulang-tkp-novel

https://www.hukumonline.com/klinik/detail/ ulasan/lt52cf2e84378f4/dasar-hukum-olah$\underline{\mathrm{tkp} /}$ 